International Conference on Ceramics, Bikaner, India International Journal of Modern Physics: Conference Series Vol. 22 (2013) 62-70

(C) World Scientific Publishing Company

DOI: $10.1142 / \mathrm{S} 2010194513009938$

\title{
MINERALOGICAL CHARACTERIZATION STUDIES ON UNBURNT CERAMIC PRODUCT MADE FROM ROCK RESIDUE ADDITIVES BY FT-IR SPECTROSCOPIC TECHNIQUE
}

\author{
R. VIJAYARAGAVAN $*^{\dagger}$ \\ * Department of Physics, Arasu Engineering College, Kumbakonam, Tamilnadu, India. \\ $\&^{\dagger}$ Research and development Centre, Bharathiar University, Coimbatore, Tamilnadu, India. \\ rvragavan123@gmail.com

\section{S. MULLAINATHAN} \\ Department of Physics, A.V.C. College of Engineering, Mayiladuthurai, Tamilnadu, India. \\ s_mullai@rediffmail.com \\ M. BALACHANDRAMOHAN \\ Department of Physics, Erode College of Arts and Science, Erode, Tamilnadu, India. \\ N. KRISHNAMOORTHY \\ Dept of Physics, CSI Engineering College, Keeti, TheNilgiris, Tamilnadu, India.
}

\section{S. NITHIYANANTHAM}

School of Physical science and Nanotechnology (Ultrasonics/Bio-Physics Divisions), SRM University, Kattankulathur, Kanchipuram District., Chennai, Tamilnadu, India.

\section{S. MURUGESAN}

Department of Physics, Sathyabama University, Chennai, Tamilnadu, India

\section{VANATHI* ${ }^{\dagger}$}

*Department of Physics, A.V.C. College of Engineering, Mayiladuthurai, Tamilnadu, India. $\&^{\dagger}$ Research and development Centre, Bharathiar University, Coimbatore, Tamilnadu, India.

\section{Received (16 October 2012)}

Revised (28 December 2012)

The usability of waste rock (rock residue) powder as an additive material in ceramic samples was investigated. Qualitative analysis was carried out to determine the major and minor constituent minerals present in ceramic bodies made from rock residue powder by using FT-IR spectroscopic technique. Further, the representative ceramic bodies are analyzed by FT-IR technique to yield more information about the functional groups and also to estimate the order or disorder of kaolinite structure.

Keywords: FT-IR Analysis; Rock Residue; Ceramic product. 


\section{Introduction}

Rock waste such as residue powders which result from cutting, polishing, crushing and machining operations in the rock quarries have a significant and serious impact on the environment. The rock waste is potentially pollutant ${ }^{1}$ although only a small part of it is correctly discarded. Most of rock waste is illegally dumped in land and in the environment. This practice causes negative effects on the environment and human health, since the fine powder in suspension can be inhaled ${ }^{2,3}$. The amount of powdery rock waste is estimated to be in the range of $20-25 \%$ of total production ${ }^{4}$.

The present research work is on the use of the waste material (rock residue) for manufacturing ceramic product. The main objective of this work is to identify and characterize the various minerals present in the ceramic products made from rock residue powder. Also to study, the order and disorder form of clay minerals and structural information about the ceramic samples using FT-IR Spectroscopic technique.

\section{Experimental}

A typical ceramic body formulated using a rock residue in the form of powder was selected as one raw material and mixture of another raw material is fire clay. The rock residue powder collected from a private rock-crushing plant located in Thuraiyur, Trichy district of Tamil Nadu, India and fire clay material collected from Govt. Ceramic institute, Virdhachalam of Tamilnadu.

The raw materials, Rock residue powder and fire clay material were dried and ground in an agate mortar. The various proportion of rock residue powder $0 \%, 10 \%, 20 \%, 30 \%$, $40 \%$ \& 50\% were mixed with Fire clay material by weight basis. The green ceramic bodies were moulded into ASTM standard rectangular bars using a uniaxial pressing technique. After forming, the ceramic body specimens were dried in open atmosphere (3 days) and then in an oven dried for 24 hours at $110{ }^{\circ} \mathrm{C}$. Six experimental ceramic bodies were named RW0, RW10, RW20, RW30, RW40 and RW50.

The rock residue powder mixed ceramic bodies (RW0-RW50) were well ground into a fine powder using agate mortar. The powder form Ceramic samples (RW0-RW50) were used for spectral studies involving FTIR

The infrared spectra were recorded in the mid IR region $4000-400 \mathrm{~cm}^{-1}$ using Perkin Elmer FTIR interferometer in Centralized Instrumentation Sophisticated Laboratory (CISL), Annamalai University. The KBr pressed pellet technique was used by mixing the powdered samples with $\mathrm{KBr}$ in weight proportion of 1: 20. The precision of the FTIR instrument is $\pm 4 \mathrm{~cm}^{-1}$ in 4000 to $2000 \mathrm{~cm}^{-1}$ region and $\pm 2 \mathrm{~cm}^{-1}$ between 2000 and $400 \mathrm{~cm}^{-1}$.

\section{Results and Discussion}

The clay minerals are the essential and basic raw materials for making ceramic products. Knowledge of the structure of the clay material goes along way in characterizing the quality of such materials. Of the various well known methods of analysis, infrared spectroscopic is found to be a potential tool in investigating the structure of clay mineral ${ }^{5}$. 
The FT-IR spectra of rock residue additives mixed Ceramic body specimens (RW0 RW50) are shown in Fig. 1 and the absorption frequencies of the peaks in the spectra of each sample in the wave number $\left(\mathrm{cm}^{-1}\right)$ and present mineral name are reported in Table 1 .

Table 1 shows the FT-IR spectral results of the Ceramic bodies from different proportions of rock residue mixture indicate the presence of Clay minerals (Kaolinite and Montmorillonite), Quartz, Hematite, Microcline (Feldspar) and Calcite. These minerals were identified by referring the reports in the literatures ${ }^{5-25}$.

The FT-IR spectra of rock residue powder mixed Ceramic bodies RW0, RW10, RW20, RW30,RW40 and RW50 is shown in Figure 1 and the peak positions of various band of varied intensity observed in the spectra along with their tentative vibrational assignments are given in the Table 2. The intensity of bands varies from sample to sample which indicates its quantity.

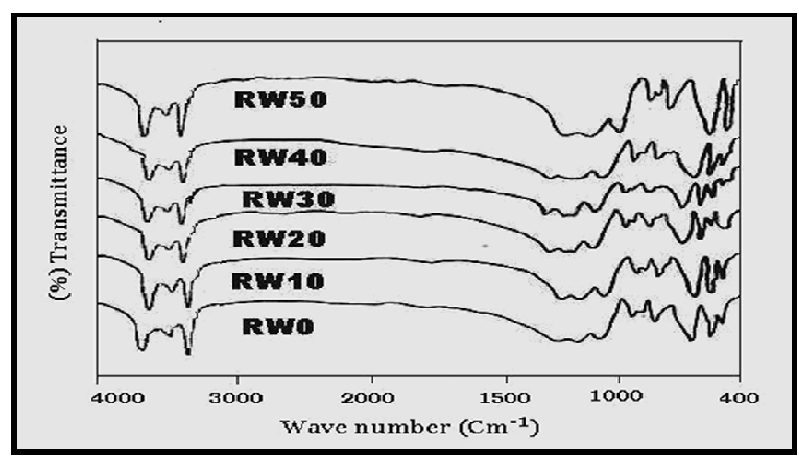

Fig.1. FT-IR Spectra of Ceramic bodies made from rock residue (0-50 wt. \%) additives

The around $3694 \mathrm{~cm}^{-1}$ strong band arises from the in phase symmetric stretching vibration of the $\mathrm{OH}$ groups, either outer or inner -surface $\mathrm{OH}$ of the octahedral sheets, which form weak hydrogen bonds with the oxygens of the next tetrahedral layer ${ }^{6}$. On the other hand, the near $3620 \mathrm{~cm}^{-1}$ strong band is due to the stretching vibrations of the "inner OH groups", lying between the tetrahedral and the octahedral sheet ${ }^{7}$.

It has been pointed out by Keeling ${ }^{8}$ that the bands at $3690 \mathrm{~cm}^{-1}$ and $3620 \mathrm{~cm}^{-1}$ can be attributed to outer and inner hydroxyl groups.

The IR spectra of the samples RW0, RW10, RW20, RW30, RW40 and RW50 show sharp absorption band around $3696 \mathrm{~cm}^{-1}$ which indicates the O-H stretching of kaolinite ${ }^{9}$ present in them.

A sharp absorption band observed $3620 \mathrm{~cm}^{-1}$ with strong to very strong intensity present in all the samples due to the $\mathrm{O}-\mathrm{H}$ stretching of inner hydroxyl group ${ }^{8-10}$.

IR Spectra of all the clay minerals are very nearly similar indicating that the constituents are almost the same. Hence, Keeling ${ }^{8}$ pointed out the clay minerals can be characterized by general formula.

$$
\left.\mathrm{Si}_{4} \mathrm{O}_{6}\left[\mathrm{O}_{4}(\mathrm{OH})_{2}\right][\mathrm{AlFe}]_{4-2 \mathrm{n}}^{3+} \mathrm{X}_{\mathrm{n}}^{2+}\right] \mathrm{OH}_{6-4 \mathrm{n}}
$$


Where, the value of $n$ lies between 0 to 1 . One of the features of this series is that the proportion of outer $(\mathrm{OH})$ groups decreases as $n$ increases. The main features of the clay minerals absorption spectra are (i) the hydrogen bonding of the structural $\mathrm{OH}$ groups and (ii) Si-O and Al-O vibration in the tetrahedral and octahedral sub layers and other associated oxide minerals.

Table 1. Mineral constituents ${ }^{5-25}$ in the rock residue mixed Ceramic bodies (RW0-RW50)

\begin{tabular}{|c|c|c|c|c|c|c|}
\hline \multirow{2}{*}{$\begin{array}{l}\text { Mineral } \\
\text { Name }\end{array}$} & \multicolumn{6}{|c|}{ IR absorption band $\left(\mathrm{cm}^{-1}\right)$} \\
\hline & RW0 & RW10 & RW20 & RW30 & RW40 & RW50 \\
\hline \multirow{14}{*}{ 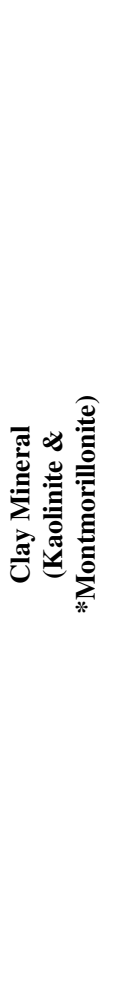 } & $\begin{array}{l}3696 \\
\operatorname{sh} \& \mathrm{M}\end{array}$ & $\begin{array}{l}3696 \\
\mathrm{VS}\end{array}$ & $\begin{array}{l}3696 \\
\text { sh \& V S }\end{array}$ & $\begin{array}{l}3696 \\
\text { sh \& V S }\end{array}$ & $\begin{array}{l}3696 \\
\text { sh \& V S }\end{array}$ & $\begin{array}{l}3692 \\
\text { sh \& S }\end{array}$ \\
\hline & $3673 \mathrm{M}$ & $3673 \mathrm{~S}$ & - & - & - & - \\
\hline & $3668 \mathrm{M}$ & $3668 \mathrm{~S}$ & $3668 \mathrm{~S}$ & $\begin{array}{l}3669 \\
\text { sd \& S }\end{array}$ & $3669 \mathrm{~S}$ & $\begin{array}{l}3670 \\
\text { sh \& M }\end{array}$ \\
\hline & $3654 \mathrm{M}$ & $\begin{array}{l}3654 \\
\text { sh \& S }\end{array}$ & $3654 \mathrm{~S}$ & $\begin{array}{l}3652 \\
\text { sh \& S }\end{array}$ & $\begin{array}{l}3651 \\
\text { sh \& S }\end{array}$ & $\begin{array}{l}3651 \\
\text { sh \& S }\end{array}$ \\
\hline & $3648 \mathrm{M}$ & - & - & - & $* 3448 \mathrm{~W}$ & $\begin{array}{l}* 3460 \\
\text { bd \& W }\end{array}$ \\
\hline & $\begin{array}{l}3620 \\
\text { sh \& S }\end{array}$ & $\begin{array}{l}3620 \\
\text { sh \& V.S }\end{array}$ & $\begin{array}{l}3620 \\
\text { sh \& V.S }\end{array}$ & $\begin{array}{l}3620 \\
\text { sh \& V.S }\end{array}$ & $\begin{array}{l}3620 \\
\text { sh \& V.S }\end{array}$ & $\begin{array}{l}3620 \\
\text { sh \& S }\end{array}$ \\
\hline & - & $\begin{array}{l}1628 \\
\text { sd \& W }\end{array}$ & - & 1629 V.W & - & - \\
\hline & 1634 V.W & - & $\begin{array}{l}1636 \\
\text { bd \& V.W }\end{array}$ & 1636 V.W & $\begin{array}{l}1638 \\
\text { bd \& V.W }\end{array}$ & 1635 V.W \\
\hline & $1116 \mathrm{~S}$ & $\begin{array}{l}1116 \\
\text { sh \& V.S }\end{array}$ & $\begin{array}{l}1115 \\
\text { sh \& V.S }\end{array}$ & $\begin{array}{l}1116 \\
\text { sh \& V.S }\end{array}$ & $\begin{array}{l}1114 \\
\text { sh \& V.S }\end{array}$ & $\begin{array}{l}1115 \\
\text { sh \& V.S }\end{array}$ \\
\hline & 1031 V.S & 1033 V.S & $\begin{array}{l}1031 \\
\text { bd \& V.S }\end{array}$ & $\begin{array}{l}1032 \\
\text { bd \& V.S }\end{array}$ & $\begin{array}{l}1031 \\
\text { bd \& V.S }\end{array}$ & $\begin{array}{l}1033 \\
\text { bd \& VS }\end{array}$ \\
\hline & 1006 V.S & 1003 V.S & $\begin{array}{l}1006 \\
\text { bd \& V.S }\end{array}$ & $\begin{array}{l}1006 \\
\text { bd \& V.S }\end{array}$ & $\begin{array}{l}1006 \\
\text { bd \& V.S }\end{array}$ & $\begin{array}{l}1006 \\
\text { sh \& V.S }\end{array}$ \\
\hline & $\begin{array}{l}912 \\
\text { sh \& S }\end{array}$ & $\begin{array}{l}913 \\
\text { sh \& V.S }\end{array}$ & $\begin{array}{l}912 \\
\text { sh \& VS }\end{array}$ & $\begin{array}{l}912 \\
\text { sh \& VS }\end{array}$ & $\begin{array}{l}912 \\
\text { sh \& W }\end{array}$ & $\begin{array}{l}912 \\
\text { sh \& VS }\end{array}$ \\
\hline & $428 \mathrm{~S}$ & $\begin{array}{l}432 \\
\text { sh \& S }\end{array}$ & $\begin{array}{l}429 \\
\text { sh \& M }\end{array}$ & $431 \mathrm{~S}$ & $\begin{array}{l}431 \\
\text { sh \& M }\end{array}$ & $\begin{array}{l}431 \\
\text { sh \& W }\end{array}$ \\
\hline & - & $\begin{array}{l}424 \\
\text { sh \& S }\end{array}$ & - & $427 \mathrm{~S}$ & - & - \\
\hline \multirow[t]{4}{*}{ Quartz } & $794 \mathrm{~W}$ & $\begin{array}{l}795 \\
\text { sh \& M }\end{array}$ & $\begin{array}{l}793 \\
\text { sh \& W }\end{array}$ & $\begin{array}{l}793 \\
\text { sh \& M }\end{array}$ & $\begin{array}{l}793 \\
\text { sh \& W }\end{array}$ & $\begin{array}{l}794 \\
\text { sh \& W }\end{array}$ \\
\hline & $694 \mathrm{~W}$ & $\begin{array}{l}695 \\
\text { sh \& M }\end{array}$ & $\begin{array}{l}695 \\
\text { sh \& M }\end{array}$ & $\begin{array}{l}695 \\
\text { sh \& M }\end{array}$ & $\begin{array}{l}695 \\
\text { sh \& M }\end{array}$ & $\begin{array}{l}695 \\
\text { sh \& W }\end{array}$ \\
\hline & $467 \mathrm{~S}$ & 469 V.S & $\begin{array}{l}466 \\
\text { sh \& V.S }\end{array}$ & $\begin{array}{l}468 \\
\text { sh \& V.S }\end{array}$ & $\begin{array}{l}468 \\
\text { sh \& V.S }\end{array}$ & $\begin{array}{l}468 \\
\text { sh \& M }\end{array}$ \\
\hline & - & 465 V.S & - & - & - & - \\
\hline Hematite & $538 \mathrm{~S}$ & $\begin{array}{l}534 \\
\text { sh \& V.S }\end{array}$ & $\begin{array}{l}539 \\
\text { sh \& V.S }\end{array}$ & $\begin{array}{l}537 \\
\text { sh \& V.S }\end{array}$ & $\begin{array}{l}536 \\
\text { sh \& V.S }\end{array}$ & $\begin{array}{l}539 \\
\text { sh \& S }\end{array}$ \\
\hline Microcline & - & $648 \mathrm{~W}$ & - & - & - & - \\
\hline Calcite & 1825 V.W & 1822 V.W & 1830 V.W & 1819 V.W & 1822 V.W & 1823 V.W \\
\hline
\end{tabular}




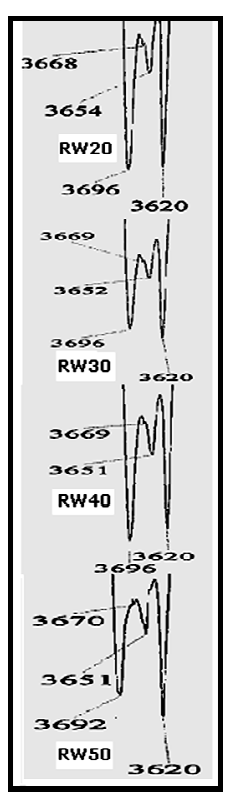

Ramaswamy and Kamalakkannan ${ }^{5}$ observed that the ratio of the intensities of $3690 \mathrm{~cm}^{-1}$ to $3620 \mathrm{~cm}^{-1}$ band that this ratio is $\approx 1$ in the case of well order clay mineral while it 0.25 in disorder ones. This ratio is a measure of the degree of disorder and can be correlated with the hydroxyl deficiency.

According to Russell ${ }^{11}$ and Ramasamy et al. ${ }^{12,}{ }^{13}$, if four peaks are observed in the region $3697-3620 \mathrm{~cm}^{-1}$, the minerals are said to be ordered state. However, in the present study four peaks are observed at (near) $3696 \mathrm{~cm}^{-1}, 3668 \mathrm{~cm}^{-1}, 3651 \mathrm{~cm}^{-1}$ and $3620 \mathrm{~cm}^{-1}$ in some samples (RW20-RW50). This suggests the minerals may be in order state and the IR Spectra of these samples with four peaks between the ranges from 3696 to $3620 \mathrm{~cm}^{-1}$ reflecting the crystalline order of Kaolinite is shown in Fig. 2. Farmer \& Russell ${ }^{14}$ and Miller ${ }^{15}$ assigned the

Fig. 2. FT-IR Spectra of ceramic samples with four peaks between the ranges from 3696 to $3620 \mathrm{~cm}^{-1}$ reflecting the crystalline order of Kaolinite. absorption band at $3620 \mathrm{~cm}^{-1}$ as due to hydroxyl group on the side of the tetrahedral sheet.

The sample RW0, RW10 and RW40 which show the absorption band positioned $3569-3565 \mathrm{~cm}^{-1}$ and $3460 \mathrm{~cm}^{-1}$ may be assigned to $\mathrm{H}-\mathrm{O}-\mathrm{H}$ vibration of adsorbed water ${ }^{16}$ and the presence of weak shoulder bands at $3586 \mathrm{~cm}^{-1}, 3544 \mathrm{~cm}^{-1}$ and $3537 \mathrm{~cm}^{-1}$ are attributed to $\mathrm{O}-\mathrm{H}$ stretching of water coordinate to $\mathrm{Al}, \mathrm{Mg}$. The characteristics bands observed $3448 \mathrm{~cm}^{-1}$ and $1628-1638 \mathrm{~cm}^{-1}$ is attributed to $\mathrm{O}-\mathrm{H}$ stretching and H-O-H bending of adsorbed water molecules ${ }^{16,17}$.

Lara Maritan et.al ${ }^{18}$ and Colombini et.al ${ }^{19}$ have reported that two weak peaks observed at $2852 \mathrm{~cm}^{-1}$ and $2922 \mathrm{~cm}^{-1}$ are due to $\mathrm{C}-\mathrm{H}$ stretching mode and reveal the presence of some organic contribution. The IR peaks corresponding range 2922-2926 $\mathrm{cm}^{-1}, 2853 \mathrm{~cm}^{-1}$ and $2954 \mathrm{~cm}^{-1}$ is due to $\mathrm{C}-\mathrm{H}$ stretching of organic matter ${ }^{18,19}$ present in all the ceramic bodies. IR spectra of rock residue powder mixed ceramic samples (RW0RW50) shows the presence of very weak absorption band $1880-1887 \mathrm{~cm}^{-1}$ and this band indicates the presence of calcite stretching vibration ${ }^{20}$.

The infrared absorption bands at (around) $1620 \mathrm{~cm}^{-1}$ has been assigned to $\mathrm{H}-\mathrm{O}-\mathrm{H}$ bending of water ${ }^{16 .}$

All the ceramic samples give very strong band in the region $1100-1000 \mathrm{~cm}^{-1}$ which is characteristic of silicate minerals.

Ghosh ${ }^{21}$ has stated that the position of the silicate band with the intense absorption at $1030 \mathrm{~cm}^{-1}$ indicates red clay origin and around $1070 \mathrm{~cm}^{-1}$ due to white clay origin. If the absorption band is observed around $1040 \mathrm{~cm}^{-1}$, it is probably due to the mixture of both red and white clay origin. In case of all the samples have silicate band is found to be centered around $1030 \mathrm{~cm}^{-1}$ with very strong intensity indicating red clay origin of the kaolinite clay used in making the ceramic product ${ }^{22,23}$.

In the present IR spectra, three important absorption bands are observed (near) 1114 $\mathrm{cm}^{-1,} 1003-1006 \mathrm{~cm}^{-1}$ and $1030-1033 \mathrm{~cm}^{-1}$ for ceramic samples (RW0-RW50). The very 
Table 2. FT-IR Spectroscopic results of rock residue powder mixed Ceramic bodies

\begin{tabular}{|c|c|c|c|c|c|c|}
\hline RW0 & RW10 & RW20 & RW30 & RW40 & RW50 & $\begin{array}{l}\text { Tentative vibrational } \\
\text { assignment }\end{array}$ \\
\hline $\begin{array}{l}3696 \\
\text { sh \& M }\end{array}$ & $\begin{array}{l}3696 \\
\text { V.S }\end{array}$ & $\begin{array}{l}3696 \\
\text { sh \& V.S }\end{array}$ & $\begin{array}{l}3696 \\
\text { sh \& V.S }\end{array}$ & $\begin{array}{l}3696 \\
\text { sh \& V.S }\end{array}$ & $\begin{array}{l}3692 \\
\text { sh \& S }\end{array}$ & $\begin{array}{l}\text { O-H stretching of } \\
\text { hydroxyl sheet }\end{array}$ \\
\hline $\begin{array}{l}3673 / 3668 \\
M\end{array}$ & $\begin{array}{l}3673 / 3668 \\
S\end{array}$ & $3668 \mathrm{~S}$ & $\begin{array}{l}3669 \\
\text { sd \& S }\end{array}$ & $3669 \mathrm{~S}$ & $\begin{array}{l}3670 \\
\text { sh \& M }\end{array}$ & $\begin{array}{l}\text { O-H Stretching of inner- } \\
\text { surface hydroxyl group }\end{array}$ \\
\hline $\begin{array}{l}3654 / \\
3648 \mathrm{M}\end{array}$ & $\begin{array}{l}3654 \\
\text { sh \& S }\end{array}$ & $3654 \mathrm{~S}$ & $\begin{array}{l}3652 \\
\text { sh \& S }\end{array}$ & $\begin{array}{l}3651 \\
\text { sh \& S }\end{array}$ & $\begin{array}{l}3651 \\
\text { sh \& S }\end{array}$ & \\
\hline $\begin{array}{l}3620 \\
\text { sh \& S }\end{array}$ & $\begin{array}{l}3620 \\
\text { sh \& V.S }\end{array}$ & $\begin{array}{l}3620 \\
\text { sh \& V.S }\end{array}$ & $\begin{array}{l}3620 \\
\text { sh \& V.S }\end{array}$ & $\begin{array}{l}3620 \\
\text { sh \& V.S }\end{array}$ & $\begin{array}{l}3620 \\
\text { sh \& S }\end{array}$ & $\begin{array}{l}\text { O-H stretching inner } \\
\text { hydroxyl group }\end{array}$ \\
\hline $\begin{array}{l}3586 \\
\text { sd \& W }\end{array}$ & - & - & - & - & - & $\begin{array}{l}\mathrm{O}-\mathrm{H} \text { stretching of water } \\
\text { co ordinate to } \mathrm{Al}, \mathrm{Mg}\end{array}$ \\
\hline $\begin{array}{l}3565 \\
\text { sd \& W }\end{array}$ & $\begin{array}{l}3566 \\
\text { sd \& M }\end{array}$ & - & - & $\begin{array}{l}3569 \\
\text { sd \& W }\end{array}$ & - & $\mathrm{H}-\mathrm{O}-\mathrm{H}$ adsorbed water \\
\hline- & $\begin{array}{l}3544 \\
\text { sd \& W }\end{array}$ & - & - & $3537 \mathrm{~W}$ & - & $\begin{array}{l}\mathrm{O}-\mathrm{H} \text { stretching of water } \\
\text { co ordinate to } \mathrm{Al}, \mathrm{Mg}\end{array}$ \\
\hline- & - & - & - & - & $\begin{array}{l}3460 \\
\text { bd \& W }\end{array}$ & $\mathrm{H}-\mathrm{O}-\mathrm{H}$ adsorbed water \\
\hline- & - & - & - & $3448 \mathrm{~W}$ & - & $\mathrm{O}-\mathrm{H}$ stretching of water \\
\hline $\begin{array}{l}2922 \\
\text { V.W }\end{array}$ & 2925 V.W & $\begin{array}{l}2925 \\
\text { sh \& } \\
\text { V.W }\end{array}$ & 2926 V.W & $\begin{array}{l}2926 \\
\text { V.W }\end{array}$ & $\begin{array}{l}2923 \\
\text { V.W }\end{array}$ & $\begin{array}{l}\text { C-H Stretching of organic } \\
\text { matter }\end{array}$ \\
\hline 2853 V.W & 2854 V.W & $\begin{array}{l}2853 \\
\text { sh \& } \\
\text { V.W }\end{array}$ & 2854 V.W & $\begin{array}{l}2854 \\
\text { V.W }\end{array}$ & $\begin{array}{l}2854 \\
\text { V.W }\end{array}$ & $\begin{array}{l}\text { C-H Stretching of organic } \\
\text { matter }\end{array}$ \\
\hline $\begin{array}{l}1825 \\
\text { V.W }\end{array}$ & $\begin{array}{l}1822 \\
\text { V.W }\end{array}$ & $\begin{array}{l}1830 \\
\text { V.W }\end{array}$ & 1819 V.W & $\begin{array}{l}1822 \\
\text { V.W }\end{array}$ & $\begin{array}{l}1823 \\
\text { V.W }\end{array}$ & $\begin{array}{l}\text { Calcite stretching } \\
\text { vibration }\end{array}$ \\
\hline $\begin{array}{l}1634 \\
\text { V.W }\end{array}$ & $\begin{array}{l}1628 \\
\text { sd \& W }\end{array}$ & $\begin{array}{l}1636 \\
\text { bd \& } \\
\text { V.W }\end{array}$ & $\begin{array}{l}1629 \\
/ 1636 \\
\text { V.W }\end{array}$ & $\begin{array}{l}1638 \\
\text { bd \& } \\
\text { V.W }\end{array}$ & $\begin{array}{l}1635 \\
\text { V.W }\end{array}$ & $\mathrm{H}-\mathrm{O}-\mathrm{H}$ adsorbed water \\
\hline- & - & - & 1653 V.W & - & - & $\mathrm{O}-\mathrm{H}$ deformation of water \\
\hline $1116 \mathrm{~S}$ & $\begin{array}{l}1116 \\
\text { sh \& V.S }\end{array}$ & $\begin{array}{l}1115 \\
\text { sh \& V.S }\end{array}$ & $\begin{array}{l}1116 \\
\text { sh \& V.S }\end{array}$ & $\begin{array}{l}1114 \\
\text { sh \& V.S }\end{array}$ & $\begin{array}{l}1115 \\
\text { sh \& V.S }\end{array}$ & {$\left[\mathrm{Al}-\mathrm{O}-(\mathrm{OH})_{6}\right]$} \\
\hline 1031 V.S & 1033 V.S & $\begin{array}{l}1031 \\
\text { bd \& V.S }\end{array}$ & $\begin{array}{l}1032 \\
\text { bd \& V.S }\end{array}$ & $\begin{array}{l}1031 \\
\text { bd \& V.S }\end{array}$ & $\begin{array}{l}1033 \\
\text { bd \& VS }\end{array}$ & $\mathrm{Si}-\mathrm{O}$ of stretching \\
\hline 1006 V.S & 1003 V.S & $\begin{array}{l}1006 \\
\text { bd \& V.S }\end{array}$ & $\begin{array}{l}1006 \\
\text { bd \& V.S }\end{array}$ & $\begin{array}{l}1006 \\
\text { bd \& V.S }\end{array}$ & $\begin{array}{l}1006 \\
\text { sh \& V.S }\end{array}$ & $\mathrm{Si}-\mathrm{O}$ of stretching \\
\hline $\begin{array}{l}912 \\
\text { sh \& S }\end{array}$ & $\begin{array}{l}913 \\
\text { sh \& V.S }\end{array}$ & $\begin{array}{l}912 \\
\text { sh \& VS }\end{array}$ & $\begin{array}{l}912 \\
\text { sh \& VS }\end{array}$ & $\begin{array}{l}912 \\
\text { sh \& W }\end{array}$ & $\begin{array}{l}912 \\
\text { sh \& VS }\end{array}$ & $\mathrm{Al}-(\mathrm{OH})$ \\
\hline $794 \mathrm{~W}$ & $\begin{array}{l}795 \\
\text { sh \& M }\end{array}$ & $\begin{array}{l}793 \\
\text { sh \& W }\end{array}$ & $\begin{array}{l}793 \\
\text { sh \& M }\end{array}$ & $\begin{array}{l}793 \\
\text { sh \& W }\end{array}$ & $\begin{array}{l}794 \\
\text { sh \& W }\end{array}$ & $\mathrm{Si}-\mathrm{O}$ of quartz \\
\hline 754 V. W & $\begin{array}{l}755 \\
\text { sh \& W }\end{array}$ & $\begin{array}{l}754 \\
\text { sh \& W }\end{array}$ & $\begin{array}{l}754 \\
\text { sh \& W }\end{array}$ & $\begin{array}{l}754 \\
\text { sh \& W }\end{array}$ & $\begin{array}{l}755 \\
\text { sh \& W }\end{array}$ & Al-O-Si \\
\hline $694 \mathrm{~W}$ & $\begin{array}{l}695 \\
\text { sh \& M }\end{array}$ & $\begin{array}{l}695 \\
\text { sh \& M }\end{array}$ & $\begin{array}{l}695 \\
\text { sh \& M }\end{array}$ & $\begin{array}{l}695 \\
\text { sh \& M }\end{array}$ & $\begin{array}{l}695 \\
\text { sh \& W }\end{array}$ & $\mathrm{Si}-\mathrm{O}$ of quartz \\
\hline- & $648 \mathrm{~W}$ & - & - & - & - & Si-O-Al \\
\hline $538 \mathrm{~S}$ & $\begin{array}{l}534 \\
\text { sh \& V.S }\end{array}$ & $\begin{array}{l}539 \\
\text { sh \& V.S }\end{array}$ & $\begin{array}{l}537 \\
\text { sh \& V.S }\end{array}$ & $\begin{array}{l}536 \\
\text { sh \& V.S }\end{array}$ & $\begin{array}{l}539 \\
\text { sh \& S }\end{array}$ & $\mathrm{Fe}-\mathrm{O}$ of $\mathrm{Fe}_{2} \mathrm{O}_{3}$ \\
\hline $467 \mathrm{~S}$ & $\begin{array}{l}469 / 465 \\
\text { V.S }\end{array}$ & $\begin{array}{l}466 \\
\text { sh \& V.S }\end{array}$ & $\begin{array}{l}468 \\
\text { sh \& V.S }\end{array}$ & $\begin{array}{l}468 \\
\text { sh \& V.S }\end{array}$ & $\begin{array}{l}468 \\
\text { sh \& M }\end{array}$ & $\begin{array}{l}\text { Si-O-Si bending of } \\
\text { silicates }\end{array}$ \\
\hline $428 \mathrm{~S}$ & $\begin{array}{l}432 \text { / } 424 \\
\text { sh \& S }\end{array}$ & $\begin{array}{l}429 \\
\text { sh \& M }\end{array}$ & $\begin{array}{l}431 / 427 \\
S\end{array}$ & $\begin{array}{l}431 \\
\text { sh \& M }\end{array}$ & $\begin{array}{l}431 \\
\text { sh \& W }\end{array}$ & $\mathrm{Si}-\mathrm{O}$ of mixed vibration \\
\hline
\end{tabular}


strong broad band, near $1114 \mathrm{~cm}^{-1}$, is due to [Al-O- $\left.(\mathrm{OH})_{6}\right]$. This band is investigated by Percival et al. ${ }^{10}$. The $1003-1006 \mathrm{~cm}^{-1}$ and $1030-1033 \mathrm{~cm}^{-1}$ band is attributed to the Si-O stretching vibration present in all ceramic samples. From the FTIR study, the absorption bands at $912 \mathrm{~cm}^{-1}$ and $913 \mathrm{~cm}^{-1}$ is due to Al-(OH) vibrations ${ }^{10,24}$ present in all the ceramic samples.

According to Miller ${ }^{15}$, the well order clay minerals are characterized by the presence of $920 \mathrm{~cm}^{-1}, 1120 \mathrm{~cm}^{-1}$ and $1030 \mathrm{~cm}^{-1}$ band. The many reasonable IR peaks (near 1114 $\mathrm{cm}^{-1,} 1030 \mathrm{~cm}^{-1} \& 910 \mathrm{~cm}^{-1}$ ) are present in all the ceramic samples. This indicate that the well order of clay mineral structure.

All these samples show the absorption band of 793-795 $\mathrm{cm}^{-1}$ and near $694 \mathrm{~cm}^{-1}$ which are attributed of Si-O modes of quartz ${ }^{11}$. The weak IR absorption bands are attributed at $754 \mathrm{~cm}^{-1}$ and $755 \mathrm{~cm}^{-1}$. These bands indicate that Al-O-Si inner surface vibration ${ }^{25}$ is present in all the ceramic samples.

According to Elass and Oliver ${ }^{26}$, the presence of the sharp band at $694 \mathrm{~cm}^{-1}$ indicates thin particles and in this case of thick particle, this band would shift to $689 \mathrm{~cm}^{-1}$. Since all the ceramic samples show this band at $694 \mathrm{~cm}^{-1} \& 695 \mathrm{~cm}^{-1}$ it is clear that all these samples contain quartz of thin particle size. The many authors ${ }^{27,28}$ are reported the quartz with small (thin) particle size, improves mechanical strength. By contrast, large size particles tend to decrease the mechanical strength due to micro-crack formation.

According to Lyon ${ }^{29}$, the IR peaks at $648-641 \mathrm{~cm}^{-1}$ are diagnostic of microcline. Since IR spectra of the sample (RW10) shows the infrared absorption peak in the range of $648 \mathrm{~cm}^{-1}$ it indicates the presence of microcline form of feldspar. This band does not appear in all samples (except RW10) and indicates the absence of microcline.

All the samples show very strong absorption peak around $535 \mathrm{~cm}^{-1}$ they are due $\mathrm{Fe}-\mathrm{O}$ of $\mathrm{Fe}_{2} \mathrm{O}_{3}$ (hematite). This band shows that the crystalline hematite mineral ${ }^{21,30}$.

The bands at $465-469 \mathrm{~cm}^{-1}$ and $424-432 \mathrm{~cm}^{-1}$ have assigned to Si-O-Si bending and $\mathrm{Si}-\mathrm{O}$ mixed vibration mode ${ }^{31,32}$ present in all the ceramic samples.

\section{Conclusions}

The results presented and discussed along this report enable the following conclusions to be drawn:

- The qualitative mineral identification of ceramic bodies was carried out by FT-IR Spectroscopic technique.

- The FT-IR spectral analysis of Ceramic bodies from different proportions of rock residue mixture indicate the presence of Clay minerals (Kaolinite and Montmorillonite), Quartz, Hematite, Microcline and Calcite.

- All the samples studied in the present investigation are order form of Kaolinite (clay minerals).

- The bands at near $3696 \mathrm{~cm}^{-1}$ and $3620 \mathrm{~cm}^{-1}$ assigned outer and inner hydroxyl stretching vibration of the Kaolinite structure is present in all the ceramic samples made from rock residue. 
- The presence of Aluminium and iron groups are indicated by the absorption peaks near $912-913 \mathrm{~cm}^{-1}$ and $534-539 \mathrm{~cm}^{-1}$.

- The 694 and $695 \mathrm{~cm}^{-1}$ peak absorption is the indication of quartz particle present in the sample as thin (small) size. This quartz with small particle size, improves mechanical strength of the ceramic bodies.

- It is important to note that FT-IR spectra obtained for pure clay ceramic body sample (RW0) as well as rock residue mixed ceramic body samples (RW10-RW50) are almost identical.

The present study demonstrates usefulness of spectroscopic techniques in determining quality of ceramic samples made from $10-50 \mathrm{wt}$. \% of rock residue additives.

\section{References}

1. C. Simsek, Z. Karaca, U. Gemici and O. Gunduz, Fres. Environ. Bull. 14(11), 1013 (2005).

2. G. Rego, C. Martinez, A. Quero, T.P. Blanco and J. M. Barquea, Med. Clin. 116(8), 290 (2001).

3. P. Torres, H.R. Fernades, S. Agathopoulus, D.U. Tulyaganov and J.M.F. Ferreira, Journal of the European Ceramic Society 24(10-11), 3177 (2004).

4. R.R. Menezes, H.S. Ferreira, G.A. Neves and H.C. Ferreira, Journal of the European Ceramic Society 25(7), 1149 (2005).

5. K. Ramaswamy and M. Kamalakkannan, Indian Journal of pure and applied Physics 25, 284 (1987).

6. E. Balan, A.M. Saitta, F. Mauri and G. Calas, American mineral. 86, 1321 (2001).

7. J. Madejova, M. Janek, P. Komadel, H.J. Herbert, and H.C. Moog, Applied clay science 20, 255 (2002).

8. P. S. Keeling, Trans. Brit. Ceram. Soc, 62, 549 (1963).

9. R. Palanivel and G. Velraj, Indian Journal of Pure and applied sciences 45, 501 (2007).

10. H. J. Percival, J. F. Ducan and P. K. Foster, J. Am. Ceram. Soc. 57, 57 (1974).

11. J.D. Russell, A Handbook of determinative methods in clay mineralogy in: Infrared methods, ed. M. J. Wilson (Chapman \& Hall, London, 1987) p. 133.

12. V. Ramasamy, S. Murugesan and S. Mullainathan, Bulletin of pure and applied sciences 23(1-2), 1 (2004).

13. V. Ramasamy and G.Suresh, American-Eurasian Journal of Scientific research 4(2), 103 (2009).

14. V.C. Farmer and J.D. Russel, Spectrochim.Acta 20, 1149 (1964).

15. J.G. Miller, Journal Material Science 63, 800 (1961).

16. Jana Madejova and Peter Komadel. Clays and Clay Minerals 49(5), 410 (2001).

17. E. Maleolm, and R. Summer, Hand book of the Soil Science, ed. Boca Raton (University of Georgio, Hondor, Newyork, 1995) p. 111.

18. Lara Maritan, Claudio Mazzoli, Luca Nodari and Umbeeto Russo, Applied clay science 29, 31 (2005).

19. M.P. Colombini, G. Giachi, F. Modugno and E. Ribechini, Micro Chemical Journal 79, 83 (2005).

20. M.A. Legodi and D. de Waal, Spectrochim. Acta Part-A 66, 135 (2007).

21. S.N. Ghosh, Journal Material science 13, 1877 (1978).

22. G. Viruthagiri, Spectroscopical characterization of some bricks and clays collected in Cuddalore District of Tamil nadu, Ph.D. Thesis, Annamalai University, India (2005). 
23. G. Viruthagiri, K. Ponnarasi, G. Gandhimathi and B. Rajammanan, Advances in Applied Science research 2(4), 251 (2011).

24. K. Ramaswamy and M. Kamalakkannan, Journal of Thermal Analysis 44, 629 (1995).

25. J. Hlavay, K. Jonas, S. Elek and J. Inczedy, Clays and Clay minerals 25, 451 (1978).

26. F. Elass and D. Oliver, Clay Minerals 13, 299 (1978).

27. C.M.F. Vieira, L.A. Pecanha and S.N. Monteiro, Ceramica 52, 138 (2006).

28. R. Vijayaragavan and S. Mullainathan, Material Science Research India, 8(2), 321 (2011).

29. R.J.P. Lyon, Physical methods in determinative mineralogy, in Infrared absorption spectroscopy, ed. J. Zussman (Academic press, New York, 1967) p. 371.

30. S.V. Sajeev, Infrared Spectroscopic and magnetic studies of some archaeological sites in south India, Ph.D thesis, Annamalai University, Tamilnadu,India (1996).

31. J.J. Fripat and F. Toussaint, Nature 186, 627 (1960).

32. Bhaskar J. Saikia and Gopalakrishnarao Parthasarathy, J. Modern Physics 1, 206 (2010). 